\title{
Influence of Area and Yield on the Production of Rice in Chhattisgarh Plain
}

\author{
Ghananand Sahu $^{1 *}$, Dikeshwar Nishad ${ }^{2}$ and M.L. Lakhera ${ }^{1}$ \\ ${ }^{1}$ Indira Gandhi Krishi Vishwavidyalaya, Raipur 492012, Chhattisgarh, India \\ ${ }^{2}$ Bidhan Chandra Krishi Vishwavidyalaya, Mohanpur 741252, Nadia (W.B.), India \\ *Corresponding author
}

\begin{tabular}{|c|c|}
\hline \multicolumn{2}{|r|}{ A B S T R A C T } \\
\hline & \multirow{5}{*}{$\begin{array}{l}\text { Predictive models for the rice crop (Oryza sativa L.) of Chhattisgarh plain and its } \\
\text { constituent districts have been made. Models have been fitted for the area, } \\
\text { productivity and production of the crop separately for above region. Based on } \\
\text { these models prediction of area productivity and production of rice have been } \\
\text { made year wise between } 1998-99 \text { to } 2013-14 \text {. The partial compound growth rates } \\
\text { of the area, production and productivity of the crop have been also estimated and } \\
\text { discussed. Periodic effect of five years as well as annual effects was found to be } \\
\text { working in most of the districts/region based on a postulated and estimated } \\
\text { production function of area and productivity. It was found that the major } \\
\text { influencing factor on the production of rice was its area. This influence of area } \\
\text { was around } 60 \text { percent for mostly districts of the Chhattisgarh plain. }\end{array}$} \\
\hline Keywords & \\
\hline $\begin{array}{l}\text { Growth rate, Area, } \\
\text { Production and } \\
\text { Rice. }\end{array}$ & \\
\hline Article Info & \\
\hline $\begin{array}{l}\text { Accepted: } \\
\text { 17 September } 2017 \\
\text { Available Online: } \\
\text { 10 October } 2017\end{array}$ & \\
\hline
\end{tabular}

\section{Introduction}

India accounts for only about $2.4 \%$ of the world's geographical area and $4 \%$ of its water resources, but has to support about 17 $\%$ of the world's human population and $15 \%$ of the livestock. Agriculture is an important sector of the Indian economy, accounting for $14 \%$ of the nation's GDP, about $11 \%$ of its exports, about half of the population still relies on agriculture as its principal source of income and it is a source of raw material for a large number of industries. It occupies $32 \%$ of the area under food grains and contributes $42 \%$ of total food grains production in the country. During 2011-12, there was record production of food grains at 259.32 million tones, of which 131.27 million tones was during Kharif season and 128.05 million tons during the Rabi season. Of the total food grains production, production of cereals was 242.23 million tones the production of rice (both kharif and rabi) is estimated at 101.8 million tones (Ghosh, 2011).

Agriculture is counted as the chief economic occupation of the Chhattisgarh state. According to a government estimate, net sown area of the state is 4.828 million hectares and the gross sown area is 5.788 million hectares. About $80 \%$ of the population of the state is rural and the main livelihood of the villagers is agriculture and agriculture based small industry. Paddy is main crop of Chhattisgarh. Chhattisgarh is popularly known as "rice bowl" of India and occupies 
an area of around 3.61 million hectare with the production of $5.4 \mathrm{mt}$. and productivity of $1517 \mathrm{~kg} / \mathrm{ha}$ (Anonymous, 2010b). The productivity of rice in the state is 1.52 tone/ ha, which is far behind the productivity of India (1.9 tone/ ha), china (6.3 tone/ ha), Japan (6.4 tone/ ha) and Egypt (8.4 tone/ ha).The present study is therefore, an attempt had been made to develop reliable predictive models for the area, production and productivity of cereals for Chhattisgarh Plain, its constituent districts. Production function had also been developed to know the extent of influence of area and productivity on production.

\section{Materials and Methods}

The secondary data on area, productivity and production of rice crop were collected for the period 1998-99 to 2013-14 from the web site of Chhattisgarh Government www.cgstate.gov.in. In this period there are ten districts in Chhattisgarh plain namely Raipur, Mahasamund, Dhamtari, Durg, Rajnandgaon, Kawardha, Bilaspur, Janjgir, Korba and Raigarh due to the formation of new districts.

During analyses it was realized that a five year periodic effect is working on the response variable in most of the districts/region. Therefore, this periodic effect was considered as a structural effect changing every five years the area, production and productivity scenario of rice crop probably due to some research or technical breakthrough, etc. After fitting such structural/ periodic effects, i.e. $\alpha$ 's, it was found in most cases that they were showing a trend over the three periods in almost all districts and slopes $(\beta$ 's) were not significantly different for these periods. Due to these reasons a periodic effect variable ' $P$ ' was introduced to measure the periodic trend along with the annual effect variable ' $\mathrm{T}$ ' to measure annual trend with in each period. So, the following multiple regression models was finalized and fitted in all cases using stepwise regression technique as described.

$\ln Y=\ln t+b p P+b t T+\in(1 a)$

Or

$\ln \widehat{Y}=\ln t+b p P+b t \mathrm{~T}(1 \mathrm{~b})$

Where,

$\ln \widehat{Y}=$ expected value of the natural logarithm of the response variable.

$\mathrm{Y}=$ area, productivity (i.e. yield) or production of given a region.

$\ln \mathrm{t}=$ intercept

$\mathrm{P}=$ periodic time Variable, taking values from 1 to 3 signifying Pd I, i.e., first period for 1998-99 to 2003-04, Pd II for 2004-05 to 2008-09 and Pd III for 2009-10 to 2013-14.

$\mathrm{T}=$ annual time variable taking values from 1 to 5 signifying the $1^{\text {st }}, 2^{\text {nd }}, 3^{\text {rd }}, 4^{\text {th }}$ or $5^{\text {th }}$, year for any period 1 to 3 .

$\mathrm{bp}=$ partial linear regression coefficient corresponding to variable $\mathrm{P}$.

bt $=$ partial linear regression coefficient corresponding to variable $\mathrm{T}$.

$\in=$ error/disturbance component.

Lastly, our interest is to find the extent of influence of area and productivity on the production of cereal crops in Chhattisgarh plain. For that we need an additive model with an error term. We have the identity,

Production $=$ Area $\times$ Productivity . 
However, in actual practice the area, production and productivity are not always reported to be accurate enough to equal to above product, due to probably rounding errors and many a times due to human error in recording the data.

Therefore, assuming that actual area, production and productivity are some powers of the reported data and representing the residual discrepancies with an error term, this identity can be written in the functional form. Then, after taking natural logarithms, denoting the error compound by $\epsilon^{\prime} \sim N$ $\left(0, \sigma_{\in v}^{2}\right)$ and then introducing the intercept term we can have the following linear statistical model

$\widehat{\ln } \mathrm{P}(\mathrm{A}, \mathrm{Y})=\mathrm{c}_{0}+\mathrm{c}_{1} \ln \mathrm{A}+\mathrm{c}_{2} \ln \mathrm{Y}+\in^{\prime}(2 \mathrm{a})$

Or, $\widehat{\ln } \mathrm{P}(\mathrm{A}, \mathrm{Y})=\mathrm{c}_{0}+\mathrm{c}_{1} \ln \mathrm{A}+\mathrm{c}_{2} \ln \mathrm{Y}(2 \mathrm{~b})$

Or, $\widehat{\mathrm{P}}(\mathrm{A}, \mathrm{Y})=\mathrm{d}_{0} \mathrm{~A}^{\mathrm{c} 1} \mathrm{Y}^{\mathrm{c} 2}, \mathrm{~d}_{0}=\mathrm{e}^{\mathrm{c} 0}(2 \mathrm{c})$

Where A, Y and $\widehat{P}(\mathrm{~A}, \mathrm{P})$ denote the area, productivity and estimated production of a given region. The constant $\mathrm{c}_{0}$ is the intercept and $\left(\mathrm{c}_{1}, \mathrm{c}_{2}\right)$ are the partial regression coefficients corresponding to variables $\ln \mathrm{A}$ and $\ln \mathrm{Y}$ respectively.

\section{Results and Discussion}

Partial compound growth rate of area, production and yield of rice was for period (1998-99 to 2012-13) and presented in Table 1. It was observed that from the Table 1 Chhattisgarh plain had registered statistically significant increasing periodic partial compound growth rate in area (2.780 percent), productivity (28.617 percent) and production (32.193 percent) at 1 percent level.

The annual compound growth rate for area, productivity and production were found
(0.588 percent), (4.203 percent) and (4.816 percent) respectively and non-significant. Among all districts of the Chhattisgarh plain zone for almost the entire district's the model showed highly significant partial regression for the periodic variable area except Bilaspur, Janjgir, Korba and Raigarh districts. The time variable showed significant growth rate for Dhamatari district only (0.0347) at 5 percent level. No other district showed significant partial regression coefficient for time variable. The model showed significant partial regression coefficient for all of the districts for the variable production. No district except Dhamatari (0.1425) at 10 percent level showed significant regression coefficient for time variable under study.

While studying productivity the table 1 revealed that almost all of the districts except Korba showed significant partial growth rate. It can also be observed from the table that no district including complete Chhattisgarh plain zone showed significant growth rate for the time variable.

\section{Production function}

To know the extent of influence of area and productivity on the production of Rice the postulated production function is given by equations 2(a), 2(b) and 2(c). The estimated production in terms of area and yield for the period has been presented in Table 2 .

It revealed from Table 2 that for Rajnandgaon, Kawardha, Mahasamund and Durg districts the production function satisfactorily fits to the data as indicated by more than $70 \%$. The model showed highest $\mathrm{R}^{2}$ up to 98.898 percent for Rajnandgaon district. The column designated (1) and (2) gives the breakup of the total percent sum of squares explained by the production component, ln $\mathrm{P}$ (A, Y) in to its percent sum of square explained by the area component $\ln$ $\mathrm{A}$ and the yield component $\ln \mathrm{Y}$. 
Table.1 Prediction models (w.r.t time) of area and production under rice for C.G. plain and its constituent districts using model (1) for Period1998-99 to 2012-13

\begin{tabular}{|c|c|c|c|c|c|c|c|}
\hline District/Region & & Int & bp & $\% \mathbf{r}_{1} @$ & bt & $\% \mathbf{r}_{2} @$ & $\% \mathbf{R}^{2}$ \\
\hline \multirow{3}{*}{ Raipur } & $\mathrm{A}$ & 6.2059 & $0.0190 * * *$ & 1.9168 & 0.0060 & 0.5979 & 69.27 \\
\hline & $\mathrm{Y}$ & 6.6630 & $0.2274 * *$ & 25.5286 & -0.0022 & -0.2174 & 27.73 \\
\hline & $\mathrm{P}$ & 5.9186 & $0.2565^{* *}$ & 29.2463 & 0.0089 & 0.8921 & 33.48 \\
\hline \multirow{3}{*}{ Mahasamund } & $\mathrm{A}$ & 5.4207 & $0.0484 * * *$ & 4.9545 & 0.0025 & 0.2476 & 84.68 \\
\hline & $\mathrm{Y}$ & 6.5037 & $0.2914 * *$ & 33.8361 & -0.0103 & -1.0277 & 34.06 \\
\hline & $\mathrm{P}$ & 4.9740 & $0.3500 * * *$ & 41.9125 & -0.0027 & -0.2739 & 42.97 \\
\hline \multirow{3}{*}{ Dhamatari } & $\mathrm{A}$ & 4.7741 & $0.0725^{* *} *$ & 7.5243 & $0.0347 * *$ & 3.5273 & 66.29 \\
\hline & $\mathrm{Y}$ & 6.4899 & $0.3132 * * *$ & 36.7832 & 0.1031 & 10.8637 & 67.81 \\
\hline & $\mathrm{P}$ & 4.3155 & $0.3954 * * *$ & 48.4947 & $0.1425^{*}$ & 15.3143 & 78.80 \\
\hline \multirow{3}{*}{ Durg } & $\mathrm{A}$ & 6.0104 & $0.0357 * * *$ & 3.6387 & 0.0073 & 0.7311 & 74.28 \\
\hline & $\mathrm{Y}$ & 6.4996 & $0.2307^{*}$ & 25.9451 & 0.0500 & 5.1258 & 22.47 \\
\hline & $\mathrm{P}$ & 5.5593 & $0.2767 *$ & 31.8794 & 0.0624 & 6.4408 & 29.91 \\
\hline \multirow{3}{*}{ Rajnandgaon } & $\mathrm{A}$ & 5.4473 & $0.0461 * * *$ & 4.7221 & 0.0095 & 0.9499 & 98.29 \\
\hline & $\mathrm{Y}$ & 6.6367 & 0.1216 & 12.9260 & 0.0568 & 5.8446 & 20.74 \\
\hline & $\mathrm{P}$ & 5.1335 & $0.1779 *$ & 19.4747 & 0.0714 & 7.3984 & 34.10 \\
\hline \multirow{3}{*}{ Kawardha } & $\mathrm{A}$ & 4.4443 & $0.0327 * * *$ & 3.3265 & 0.0070 & 0.7068 & 81.14 \\
\hline & $\mathrm{Y}$ & 6.4490 & $0.1741^{*}$ & 19.0124 & 0.0630 & 6.5022 & 34.05 \\
\hline & $\mathrm{P}$ & 3.9426 & $0.2171^{* *} *$ & 24.2486 & 0.0752 & 7.8101 & 46.43 \\
\hline \multirow{3}{*}{ Bilaspur } & $\mathrm{A}$ & 5.7377 & 0.0101 & 1.0188 & 0.0047 & 0.4690 & 24.45 \\
\hline & $\mathrm{Y}$ & 6.7101 & $0.2223 * *$ & 24.9005 & 0.0107 & 1.0741 & 30.51 \\
\hline & $\mathrm{P}$ & 5.4971 & $0.2428 * *$ & 27.4786 & 0.0205 & 2.0735 & 33.86 \\
\hline \multirow{3}{*}{ Janjgir } & $\mathrm{A}$ & 5.5466 & 0.0200 & 2.0161 & -0.0041 & -0.4088 & 10.50 \\
\hline & $\mathrm{Y}$ & 6.3049 & $0.3836^{* * * *}$ & 46.7491 & 0.1106 & 11.6921 & 76.44 \\
\hline & $\mathrm{P}$ & 4.9012 & $0.4137 * * *$ & 51.2461 & 0.1116 & 11.8057 & 78.61 \\
\hline \multirow{3}{*}{ Korba } & $\mathrm{A}$ & 4.6951 & 0.0002 & 0.0167 & 0.0004 & 0.0375 & 0.35 \\
\hline & $\mathrm{Y}$ & 6.6545 & 0.1293 & 13.8082 & 0.0174 & 1.7575 & 18.03 \\
\hline & $\mathrm{P}$ & 4.3995 & $0.1396^{*}$ & 14.9867 & 0.0229 & 2.3126 & 21.67 \\
\hline \multirow{3}{*}{ Raigarh } & A & 5.4858 & 0.0009 & 0.0905 & -0.0011 & -0.1119 & 7.58 \\
\hline & $\mathrm{Y}$ & 6.6845 & $0.1868 * *$ & 20.5432 & -0.0027 & -0.2667 & 28.96 \\
\hline & $\mathrm{P}$ & 5.2200 & $0.1980^{* *}$ & 21.8935 & 0.0013 & 0.1326 & 32.66 \\
\hline \multirow{3}{*}{ Plain Zone } & $\mathrm{A}$ & 7.8156 & $0.0274 * * *$ & 2.7805 & 0.0059 & 0.5885 & 77.55 \\
\hline & $\mathrm{Y}$ & 6.5274 & $0.2517 * * *$ & 28.6167 & 0.0412 & 4.2032 & 44.51 \\
\hline & $\mathrm{P}$ & 7.4353 & $0.2791 * * *$ & 32.1929 & 0.0470 & 4.8164 & 49.35 \\
\hline
\end{tabular}

***, **, *significant at $1 \%, 5 \%$ and $10 \%$ level of significance respectively

@ \% $\mathrm{r} 1 \& \mathrm{r}_{2}$ indicate the partial compound growth rates (in percentage) corresponding to bp (partial linear regression coefficient corresponding to periodic effect variable ' $\mathrm{P}$ ') and bt (partial linear regression coefficient corresponding to time variable ' $\mathrm{T}$ ') respectively.

Table.2 Production function as influenced by the area and productivity of rice in C.G. Plainand its constituent districts for period1998-99 to 2012-13

\begin{tabular}{|c|c|c|c|c|c|c|c|c|c|c|c|}
\hline \multicolumn{2}{|c|}{ Districts/Region } & \multicolumn{7}{|c|}{ Production Function } & \multirow{2}{*}{$\begin{array}{c}\mathbf{( 1 ) *} \\
68.104\end{array}$} & $(2)^{\$}$ & \multirow{2}{*}{$\begin{array}{r}\mathbf{( 3 )}^{@} \\
70.383\end{array}$} \\
\hline Raipur & $\ln \mathrm{P}(\mathrm{A}, \mathrm{Y})=$ & -32.0674 & + & 5.5665 & $\ln \mathrm{A}$ & + & 0.0747 & $\ln \mathrm{Y}$ & & 2.279 & \\
\hline Mahasamund & $\ln \mathrm{P}(\mathrm{A}, \mathrm{Y})=$ & -14.1231 & + & 3.1386 & $\ln \mathrm{A}$ & + & 0.0146 & $\ln \mathrm{Y}$ & 77.991 & 0.097 & 78.088 \\
\hline Dhamatari & $\ln \mathrm{P}(\mathrm{A}, \mathrm{Y})=$ & -1.9607 & + & 0.6784 & $\ln \mathrm{A}$ & + & 0.2523 & $\ln Y$ & 56.311 & 21.312 & 77.623 \\
\hline Durg & $\ln \mathrm{P}(\mathrm{A}, \mathrm{Y})=$ & -19.0547 & + & 3.6109 & $\ln \mathrm{A}$ & + & 0.0471 & $\ln \mathrm{Y}$ & 77.296 & 1.340 & 78.636 \\
\hline Rajnandgaon & $\ln \mathrm{P}(\mathrm{A}, \mathrm{Y})=$ & -18.2530 & + & 3.8774 & $\ln \mathrm{A}$ & - & 0.0023 & $\ln \mathrm{Y}$ & 98.897 & 0.001 & 98.898 \\
\hline Kawardha & $\ln \mathrm{P}(\mathrm{A}, \mathrm{Y})=$ & -16.2157 & + & 4.0886 & $\ln \mathrm{A}$ & + & 0.1447 & $\ln \mathrm{Y}$ & 84.409 & 6.135 & 90.544 \\
\hline Bilaspur & $\ln \mathrm{P}(\mathrm{A}, \mathrm{Y})=$ & -7.0703 & + & 1.5655 & $\ln \mathrm{A}$ & + & 0.1884 & $\ln \mathrm{Y}$ & 20.537 & 9.947 & 30.484 \\
\hline Jajgir & $\ln \mathrm{P}(\mathrm{A}, \mathrm{Y})=$ & 0.2527 & + & 0.1058 & $\ln \mathrm{A}$ & + & 0.3346 & $\ln \mathrm{Y}$ & 4.763 & 69.553 & 74.316 \\
\hline Korba & $\ln \mathrm{P}(\mathrm{A}, \mathrm{Y})=$ & -5.0107 & + & 1.4056 & $\ln \mathrm{A}$ & + & 0.2483 & $\ln \mathrm{Y}$ & 0.421 & 16.291 & 16.711 \\
\hline Raigarh & $\ln \mathrm{P}(\mathrm{A}, \mathrm{Y})=$ & -11.1400 & + & 2.2756 & $\ln \mathrm{A}$ & + & 0.2808 & $\ln \mathrm{Y}$ & 0.144 & 25.455 & 25.599 \\
\hline Plain Zone & $\ln \mathrm{P}(\mathrm{A}, \mathrm{Y})=$ & -31.9541 & + & 4.3904 & $\ln \mathrm{A}$ & + & 0.0898 & $\ln \mathrm{Y}$ & 76.452 & 2.017 & 78.469 \\
\hline
\end{tabular}

* percent sum of squares explained by $\ln \mathrm{A}$, i.e. area effect

$\$$ percent sum of squares explained by $\ln \mathrm{Y}$, i.e. yield effect

@ Total percent sum of squares explained by $\ln \mathrm{P}(\mathrm{A}, \mathrm{Y})$ i.e. by the model (3) 
Table.3 Prediction of area, yield and production under rice for Chhattisgarh plain and its constituent district for the period 2008-09 to 2015-16*

\begin{tabular}{|c|c|c|c|c|c|c|c|c|c|c|}
\hline \multirow[b]{2}{*}{ District/region } & & \multicolumn{8}{|c|}{ YEAR } & \multirow[t]{2}{*}{$\begin{array}{c}\% \\
\text { Increase/Decrease }\end{array}$} \\
\hline & & $2008-09 * *$ & $2009-10$ & $2010-11$ & $2011-12$ & $2012-13$ & $2013-14$ & $2014-15$ & $2015-16$ & \\
\hline & $\mathrm{A}^{@}$ & 527.87 & 531.02 & 534.2 & 537.39 & 540.61 & 537.99 & 541.2 & 544.44 & 3.14 \\
\hline & $\mathrm{Y}$ & 1545 & 1542 & 1538 & 1535 & 1532 & 1940 & 1935 & 1931 & 24.98 \\
\hline \multirow[t]{3}{*}{ Raipur } & $\mathrm{P}$ & 810.1 & 817.32 & 824.61 & 831.97 & 839.39 & 1047.02 & 1056.36 & 1065.78 & 31.56 \\
\hline & $\mathrm{A}$ & 261.96 & 262.61 & 263.26 & 263.91 & 264.57 & 274.94 & 275.62 & 276.31 & 5.48 \\
\hline & $\mathrm{Y}$ & 1584 & 1568 & 1552 & 1536 & 1520 & 2120 & 2098 & 2077 & 31.12 \\
\hline \multirow[t]{3}{*}{ Mahasamund } & $\mathrm{P}$ & 412.14 & 411.01 & 409.88 & 408.76 & 407.64 & 584.88 & 583.27 & 581.68 & 41.14 \\
\hline & $\mathrm{A}$ & 152.38 & 157.75 & 163.32 & 169.08 & 175.04 & 163.85 & 169.62 & 175.61 & 15.24 \\
\hline & $\mathrm{Y}$ & 1868 & 2071 & 2296 & 2546 & 2822 & 2555 & 2833 & 3141 & 68.15 \\
\hline \multirow[t]{3}{*}{ Dhamtari } & $\mathrm{P}$ & 282.64 & 325.92 & 375.83 & 433.39 & 499.76 & 419.7 & 483.98 & 558.09 & 97.46 \\
\hline & $\mathrm{A}$ & 457.08 & 460.43 & 463.79 & 467.18 & 470.6 & 473.72 & 477.18 & 480.67 & 5.16 \\
\hline & $\mathrm{Y}$ & 1396 & 1468 & 1543 & 1622 & 1705 & 1759 & 1849 & 1943 & 39.18 \\
\hline \multirow[t]{3}{*}{ Durg } & $\mathrm{P}$ & 633.88 & 674.7 & 718.16 & 764.42 & 813.65 & 835.95 & 889.8 & 947.11 & 49.41 \\
\hline & $\mathrm{A}$ & 269.12 & 271.67 & 274.26 & 276.86 & 279.49 & 281.83 & 284.5 & 287.21 & 6.72 \\
\hline & $\mathrm{Y}$ & 1162 & 1230 & 1302 & 1378 & 1459 & 1313 & 1389 & 1470 & 26.51 \\
\hline \multirow[t]{3}{*}{ Rajnandgaon } & $\mathrm{P}$ & 310.66 & 333.64 & 358.32 & 384.83 & 413.3 & 371.15 & 398.61 & 428.11 & 37.81 \\
\hline & $\mathrm{A}$ & 94.59 & 95.26 & 95.93 & 96.61 & 97.29 & 97.74 & 98.43 & 99.12 & 4.79 \\
\hline & $\mathrm{Y}$ & 1135 & 1209 & 1287 & 1371 & 1460 & 1351 & 1438 & 1532 & 34.98 \\
\hline \multirow[t]{3}{*}{ Kawardha } & $\mathrm{P}$ & 106.6 & 114.93 & 123.9 & 133.58 & 144.01 & 132.45 & 142.8 & 153.95 & 44.42 \\
\hline & $\mathrm{A}$ & 321.43 & 322.93 & 324.45 & 325.97 & 327.5 & 324.7 & 326.22 & 327.75 & 1.97 \\
\hline & $\mathrm{Y}$ & 1616 & 1633 & 1651 & 1669 & 1687 & 2019 & 2040 & 2062 & 27.60 \\
\hline \multirow[t]{3}{*}{ Bilaspur } & $\mathrm{P}$ & 515.9 & 526.6 & 537.52 & 548.67 & 560.04 & 657.67 & 671.3 & 685.22 & 32.82 \\
\hline & $\mathrm{A}$ & 271.07 & 269.96 & 268.86 & 267.76 & 266.66 & 276.54 & 275.4 & 274.28 & 1.18 \\
\hline & $\mathrm{Y}$ & 1932 & 2158 & 2410 & 2692 & 3006 & 2835 & 3166 & 3536 & 83.02 \\
\hline \multirow[t]{3}{*}{ Janjgir } & $\mathrm{P}$ & 520.07 & 581.47 & 650.12 & 726.87 & 812.68 & 786.59 & 879.45 & 983.28 & 89.07 \\
\hline & $\mathrm{A}$ & 109.5 & 109.54 & 109.58 & 109.62 & 109.67 & 109.52 & 109.56 & 109.6 & 0.09 \\
\hline & $\mathrm{Y}$ & 1164 & 1185 & 1206 & 1227 & 1248 & 1325 & 1348 & 1372 & 17.87 \\
\hline \multirow[t]{3}{*}{ Korba } & $\mathrm{P}$ & 126.64 & 129.57 & 132.56 & 135.63 & 138.77 & 145.62 & 148.99 & 152.43 & 20.36 \\
\hline & $\mathrm{A}$ & 241.63 & 241.36 & 241.09 & 240.82 & 240.55 & 241.85 & 241.58 & 241.31 & -0.13 \\
\hline & $\mathrm{Y}$ & 1397 & 1394 & 1390 & 1386 & 1383 & 1684 & 1680 & 1676 & 19.97 \\
\hline \multirow[t]{3}{*}{ Raigarh } & $\mathrm{P}$ & 335.36 & 335.81 & 336.25 & 336.7 & 337.15 & 408.79 & 409.33 & 409.87 & 22.22 \\
\hline & $\mathrm{A}$ & 2707.49 & 2723.43 & 2739.45 & 2755.57 & 2771.79 & 2782.77 & 2799.15 & 2815.62 & 3.99 \\
\hline & $\mathrm{Y}$ & 1516 & 1579 & 1646 & 1715 & 1787 & 1949 & 2031 & 2117 & 39.64 \\
\hline Plain Zone & $\mathrm{P}$ & 4103.47 & 4301.1 & 4508.26 & 4725.4 & 4952.99 & 5424.49 & 5685.75 & 5959.6 & 45.23 \\
\hline
\end{tabular}

* predicted value $=\exp (\operatorname{lnt}+\mathrm{bp} \mathrm{P}+\mathrm{bt} \mathrm{T})$, where lnt $=$ intercept; bp and bt the partial regression coefficient corresponding to $\mathrm{P}$ and $\mathrm{T}$ cariables respectively.

** For 2008-09 to 2012-13, T= 1 to 5 for fixed $\mathrm{P}=3$; and for 2013-14 to 2015-16 T= 1 to 5 for fixed $\mathrm{P}=4$.

@ A: area in 000' ha, Y: productivity in kg/ha, P: production in 000' tones

These column (1) and (2) showed that in most of the district's the productivity influence the area of rice by more than $56 \%$ barring the districts Bilaspur, Jangrir, Korba and Raigarh. For the district Janjgir, Korba and Raigarh the productivity was influenced by the production and only a little contribution is made by the area.

\section{Prediction of area, yield and production for 2008-09 to2015-16}

Table 3 gives a prediction of area, production and productivity of rice crop for the present year (2013-14), back five years (2008-09 to 2012-13) and future two years (2014-15 to 2015-16) based on the prediction models estimated in the present study (Table 1). It is expected that the productivity of rice in Chhattisgarh plain will increase from 1516 to $2117 \mathrm{~kg} / \mathrm{ha}, \quad\{[(2117-1516) / 1516)] 100=$ $39.64 \%$, by the turn of this decade, if the present growth trend in productivity is maintained. Since the increasing in area is going to be $\{[(2815.62-2707.49) / 2707.49] 100$ $=3.99 \%\}$, the $39.64 \%$ rate of increases in productivity. It is therefore, necessary that special effort should be made to identification 
major constraints and gaps in technologies, So that the adaptation of improved technologies may be made more effective and which may ultimately result in improving the productivity at a much faster rate than the existing rate. Similarly other predictions for different districts may be obtained from the estimated models presented in table 1 .

\section{References}

Adiqa Kiani, 2008. An analysis of productivity growth and rate of return to research in agriculture sector of North West Frontier province. Sarhad Journal of Agriculture. 24(3): 521-530.

Ahmad, M.S., and Yadava, H.S. 1999. Trends in area, production and productivity of coarse cereals in Madhya Pradesh. Advances in Plant Sciences. 12(1): 191194.

Alok Shrivastava, Saxena, R.R., Lakhera, M.L., Imran Khan and Sanjay Dwivedi 2005. Annals of Biology. 21(1): 111118.

Anonymous, 1998-99 to 2012-13. Agricultural statistics, Directorate of Agriculture, Government of Madhya
Pradesh, India.

Anonymous, 1998-99 to 2012-13. Basic Agricultural Statistics, Commissioner of Land Records and Settlement Gwalior, Govt. of Madhya Pradesh.

Arun Kumar, and Mor, B.S. 2001. To analyse the growth rates in area, production and productivity of major crops in Haryana. Research on Crops. 2(3): 327-331.

Bidyut Kumar Ghosh, 2011. Determinants of the change in cropping pattern in India: 1970-71 to 2006-07. Bangladesh Development Studies. 34(2).

Draper, N. R., and H. Smith 1981. Applied Regression Analysis, pp. 241-256, 307313, John Wiley and Sons, New York.

Johnston, J., 1984. Econometrics Methods, pp. 207-233, McGraw-Hill Inc., New York.

NIN. 2002. National Nutrition Monitoring Bureau, Hyderabad.

Singh et al., 1993. Predictive models for the Area, Yield and Production of Rice in Chhattisgarh and its constituent's district along with the influence of Area and Yield on the Production- A different approach. Farm Sci. J. 6-9

\section{How to cite this article:}

Ghananand Sahu, Dikeshwar Nishad and Lakhera, M.L. 2017. Influence of Area and Yield on the Production of Rice in Chhattisgarh Plain. Int.J.Curr.Microbiol.App.Sci. 6(10): 2032-2037. doi: https://doi.org/10.20546/ijcmas.2017.610.240 